\title{
EFIKASI BEBERAPA JENIS SERBUK NABATI SEBAGAI INSEKTISIDA TERHADAP HAMA Sitophilus zeamais Motsch PADA JAGUNG DI PENYIMPANAN
}

(efficacy of several types of vegetable powder as an insecticide against Sitophilus zeamais motsch pests in corn stored)

\author{
Dinda Arina Putri ${ }^{1}$, Muhammad Sayuthi ${ }^{2}$, Alfian Rusdy ${ }^{2 *}$ \\ ${ }^{1}$ Program Studi Agroteknologi, ${ }^{2}$ Program Studi Perlindungan Tanaman, Fakultas Pertanian, \\ Universitas Syiah Kuala
}

\begin{abstract}
Abstrak. Insektisida nabati adalah insektisida yang berasal dari tumbuhan dan insektisida itu sendiri adalah bahan yang dapat digunakan untuk mengendalikan populasi Organisme Pengganggu Tanaman (OPT) terutama pada masalah penanganan pasca panen tanaman jagung. Hama Sitophilus zeamais M merupakan hama yang menyerang biji jagung sejak di lapangan dan di penyimpanan serta tingkat serangan S. zeaimais bersifat merugikan. Beberapa tumbuhan berpotensi sebagai insektisida nabati terhadap hama $S$. zeamais adalah daun babadotan (Ageratum conyzioides L), bunga cengkeh (Eugenia aromatica), daun mimba (Azadirachta indica) dan daun sirsak (Annona muricata L.). Penelitian ini menggunakan Ranangan Acak Lengkap (RAL) faktor tunggal dengan 5 pasang imago diinfestasikan pada $10 \mathrm{~g}$ masing-masing serbuk nabati dan $100 \mathrm{~g}$ biji jagung. Hasil penelitian menunjukkan bahwa serbuk bunga cengkeh efektif pada pengamatan persentase daya repelensi tertinggi yaitu $98,33 \% 2$ jam setelah aplikasi, mortalitas tertinggi yaitu $85 \% 8$ hari setelah aplikasi, lama imago muncul 9,17 (hari ke-55), jumlah imago muncul paling sedikit yaitu 0,33\% dan kerusakan biji terendah yaitu $0,46 \%$.
\end{abstract}

Kata kunci : Insektisida nabati, Sitophilus zeamais M.

\begin{abstract}
Biopesticide are insecticides derived from plants and insecticides themselves are materials that can be used to control the population of Plant Pest Organisms (OPT), especially on the problem of handling after harvesting corn crops. Sitophilus zeamais $\mathrm{M}$ pest is a pest that attacks corn seeds since in the field and is stored and the level of attack of $S$. zeaimais is detrimental. Some plants that have the potential as vegetable insecticides against $S$. zeamais pests are babadotan leaves (Ageratum conyzioides L), clove flowers (Eugenia aromatica), neem leaves (Azadirachta indica A. Juss) and soursop leaves (Annona muricata L.). This study uses a completely randomized single design (RAL) single factor with 5 pairs of imago infested in $10 \mathrm{~g}$ of each vegetable powder and $100 \mathrm{~g}$ of corn seeds. The result showed that the clove flower powder was effective in observing the highest percentage of repelency power which was $98.33 \% 2$ hours after application, the highest mortality was $85 \% 8$ days after application, imago duration appeared 9.17 (day 55), the number of imago appeared the least is $0.33 \%$ and the lowest seed damage is $0.46 \%$.
\end{abstract}

Keywords: Biopesticide, Sitophilus zeamais M.

\section{PENDAHULUAN}

Insektisida nabati adalah insektisida yang berasal dari tumbuhan, sedangkan arti insektisida itu sendiri adalah bahan yang dapat digunakan untuk mengendalikan populasi Organisme Pengganggu Tanaman (OPT). Insektisida nabati bersifat mudah terdegredasi di alam (Bio-degredable), sehingga residunya pada tanaman dan lingkungan tidak signifikan. Indonesia di kenal dengan negara yang memiliki kekayaan keanekaragaman hayati (Megabiodiversity) tersebar kedua di dunia setelah Brazil, Indonesia memiliki sejumlah tanaman yang dapat langsung digunakan sebagai bahan dasar pestisida, baik yang dapat langsung digunakan atau dengan ekstraksi sederhana dengan air, ekstraksi dengan pelarut organik lainnya ataupun dengan cara penyulingan, tergantung kepada tujuan dari formula yang akan dibuat (KPBPPP, 2012).

Petani tradisional melakukan pasca panen tanaman jagung dengan teknologi dan fasilitas yang minim.Hasil panen tongkol maupun biji jagung yang telah dijemur disimpan dalam jangka waktu yang lama hanya didalam karung. Penyebab jagung diserang hama kerena biji atau tongkol jagung dijemur hingga kadar air awal kurang dari 13\%, dengan 
berjalannya waktu kadar air dalam biji tersebut akan memperlunak tingkat kekerasan kulit sampai pada akhirnya biji jagung akan terserang. Salah satu hama yang menyerang menurut Sempel (1985) adalah Sitophilus zeamais. S. zeamais menyebabkan kerusakan antara 26-29\%, bahkan diatas $30 \%$ pada bahan yang disimpan. Oleh karena itu, sangat perlu dilakukan pemanfaatan insektisida nabati terhadap penanganan pascapanen jagung (Saenong, 2009).

Serangan hama $S$. zeamais mengakibatkan biji jagung berlubang, mudah pecah dan hancur menjadi tepung atau bubuk. Hal ini ditandai dengan terdapat tepung pada butiran yang terserang. Biji dan tepung dipersatukan oleh air liur larva sehingga kualitas biji mengalami penurunan dan kerusakan (Khalshoven, 1981 dalam Astriani, 2010). Populasi S. zeamais di tempat penyimpanan perlu dikendalikan, karena selain mengakibatkan kerusakan biji dan susut bobot, juga menyebabkan peningkatan kadar air biji sebagai hasil respirasi sehingga kondisi ini akan memacu pertumbuhan Aspergillus sp. dan terjadinya kontaminasi aflatoksin (Brown et al., 1999). Salah satu cara pengendalian yang efektif terhadap hama sasaran dan aman terhadap organisme yang bukan sasaran serta lingkungan adalah dengan menggunakan insektisida yang berasal dari tumbuhan (Martono et al., 2004).

Beberapa tumbuhan yang berpotensi sebagai insektisida nabati yaitu Babadotan (Ageratum conyzioides L), tumbuhan ini mengandung senyawa saponin, flavonoid, polifenol dan minyak atsiri yang beracun terhadap serangga (Kardinan, 1999 dalam Gani, 2010). Senyawa saponin dapat menyebabkan terhambatnya pertumbuhan dan perkembangan serangga sehingga menimbulkan kematian, selain itu juga bersifat antifeedant (penolak makan) dan menyebabkan hama mengalami gangguan proses pencernaan (Suparjo, 2008). Hasil penelitian Patty (2011) menunjukkan bahwa pemberian tepung babadotan dengan dosis $10 \mathrm{~g} / 100 \mathrm{~g}$ beras dengan jumlah serangga 20 imago Sitophilus oryzae menghasilkan persentase mortalitas pada 7 Hari Setelah Aplikasi (HSA) sebesar 45\%, pada 14 HSA sebesar 90\% dan 21 HSA mencapai $100 \%$.

Cengkeh (Eugenia aromatica) merupakan tumbuhan dengan kandungan minyak atsiri yang tinggi. Minyak atsiri dari cengkeh adalah eugenol yang memiliki aktivitas sebagai insektisida. Cengkeh dianggap berpotensi sebagai fumigan, toksisitas langsung terhadap kumbang Callosobruchus maculatus serta berpengaruh terhadap penghambatan oviposisi (Adedire \& Lajide, 2001; Longe, 2004 dalam Ofuya et al., 2010). Pada penelitian Gbaye et al. (2015) menyatakan bahwa dengan menggunakan $1 \mathrm{~g} / 10 \mathrm{~g}$ beras mampu mengendalikan hama Sitophilus oryzae dengan persentase kematian 76,70\% pada 72 jam setelah aplikasi. Mimba (Azadirachta indica A. Juss) sudah dikenal sebagai tanaman yang berpotensial sebagai insektisida nabati. Daun mimba menghasilkan beberapa metabolit sekunder yaitu azadirachtin, meliantriol atau triol, salanin, nimbin dan nimbidin (Trisnadi, 2016). Pada penelitian Ileke \& Ogungbite (2014) dengan dosis $1 \mathrm{~g} / 50 \mathrm{~g}$ beras dapat mengendalikan hama Sitophilus oryzae dengan persentase kematian $100 \%$ pada 48 jam setelah aplikasi.

Daun sirsak (Annona muricata L.) mengandung senyawa-senyawa yang berperan sebagai insektisida nabati yaitu Annoain, Acetogenin, Saponin, Flavonoid dan Tanin (Isnaini et al., 2015). Hasil penelitian Yanti (2016) daya repelensi pada 10g serbuk daun sirsak setelah 1 jam aplikasi menghasilkan persentase $86 \%$ dan persentase mortalitas dengan dosis $10 \mathrm{~g} / 100 \mathrm{~g}$ biji jagung menghasilkan 82,50\% dalam waktu 6 hari setelah aplikasi terhadap hama $S$. zeamais. Berdasarkan uraian di atas, perlu dilakukan penelitian mengenai keefektivan beberapa jenis insektisida nabati dalam mengendalikan hama $S$. zeamais di penyimpanan. 


\section{METODE PENELITIAN}

Penelitian ini dilaksanakan di Laboratorium Hama Tumbuhan, Program Studi Proteksi Tanaman, Fakultas Pertanian Universitas Syiah Kuala, Darussalam Banda Aceh. Pelaksanaan penelitian ini dimulai dari bulan Oktober 2017 sampai Februari 2018.

\section{Alat dan Bahan Penelitian}

Alat yang digunakan adalah stoples, timbangan digital, pinset, sendok, gunting, kuas, blender, ayakan 60 mesh, cawan petri, mikroskop, alat tulis dan kamera digital. Bahan yang digunakan adalah biji jagung varietas Pioner yang diperoleh dari desa Ujung Padang Kecamatan Bakongan, Aceh Selatan, kertas label, kertas karton, kain kasa, karet gelang, imago S. zeamais yang diperbanyak dari Laboratorium Hama Tumbuhan, bunga cengkeh, daun mimba, daun sirsak dan daun babadotan.

\section{Rancangan Penelitian}

Rancangan yang digunakan dalam penelitian ini adalah Rancangan Acak Lengkap (RAL) faktor tunggal yang terdiri atas 4 perlakuan serbuk nabati yaitu cengkeh, daun mimba, daun sirsak, dan daun babadotan. Tiap perlakuan diulang sebanyak 6 kali sehingga diperoleh 24 satuan unit percobaan. Adapun susunan perlakuannya dapat dilihat pada Tabel 1.

Tabel 1. Susunan Perlakuan Beberapa Serbuk Nabati

\begin{tabular}{cl}
\hline Perlakuan & Dosis Serbuk Nabati \\
\hline Serbuk Babadotan & $10 \mathrm{~g} / 100 \mathrm{~g}$ biji jagung pipil \\
Serbuk Cengkeh & $10 \mathrm{~g} / 100 \mathrm{~g}$ biji jagung pipil \\
Serbuk Daun Mimba & $10 \mathrm{~g} / 100 \mathrm{~g}$ biji jagung pipil \\
Serbuk Daun Sirsak & $10 \mathrm{~g} / 100 \mathrm{~g}$ biji jagung pipil \\
\hline
\end{tabular}

\section{Analisis Data}

Keterangan

$$
\mathrm{Yij}=\mu+\mathrm{Ni}+\sum \mathrm{ij}
$$

Yij = Hasil pengamatan perlakuan insektisida nabati pada taraf ke...i dan ulangan ke...j

$\mu \quad=$ Nilai tengah umum

$\mathrm{Ni} \quad=$ Pengaruh hasil penelitian insektisida serbuk nabati pada taraf ke...i

$\sum \mathrm{ij} \quad=$ Pengaruh galat penelitian insektisida nabati pada perlakuan ke...i dan $\mathrm{u} ;$ angan ke...j

Data hasil pengamatan pada setiap peubah dianalisis dengan RAL faktor tunggal. Data yang memiliki nilai $F$ hitung berbeda nyata dari nilai $F$ tabel maka diuji lanjut dengan Uji Beda Nyata Terkecil (BNT) pada taraf a0,05 (Gomez \& Gomez, 1995).

$$
\operatorname{BNT}(\alpha)=t_{(\alpha, \mathrm{db}) x} \frac{\sqrt{2 \mathrm{KTG}}}{\mathrm{n}}
$$

\section{Prosedur Penelitian}

\section{Pembiakan serangga $S$. zeamais}

Koleksi S. zeamais yang ada di laboratorium disortir beberapa imago dengan menggunakan kuas dan dimasukkan ke dalam stoples yang sudah diisi jagung pipil secukupnya. Kemudian ditutup dengan kain kasa dan karet gelang. Setelah 1 minggu, imago dipisahkan dari jagungdanditutup kembali. Biarkan lebih kurang satu bulan sampai imago 
turunan pertama muncul dengan tujuan mendapatkan umur yang seragam dan hama tersebut yang dijadikan sebagai serangga uji.

\section{Pembuatan Serbuk Nabati}

Tanaman babadotan dicabut, kemudian dipisahkan daunnya. Tanaman mimba dan sirsak diambil daunnya, dikeringanginkan dengan cara disebar di atas koran dan tidak dilapisi. Daun disimpan pada suhu ruang sampai daun benar-benar kering. Proses pengeringan memiliki waktu yang berbeda tergantung dari jenis ketebalan daunnya, seperti pada daun mimba membutuhkan waktu selama 2 minggu, daun sirsak dan daun babadotan selama 3 minggu. Daun yang sudah kering kemudian dihaluskan dengan blender dan diayak sehingga diperoleh serbuk yang halus. Bunga cengkeh di rajang terlebih dahulu kemudian diblender sampai halus dan disaring menggunakan ayakan.

\section{Aplikasi Serbuk Nabati pada Serangga}

Jagung pipil ditimbang sebanyak 100g dan dimasukkan ke masing-masing stoples perlakuan. Serbuk nabati ditimbang sebanyak $10 \mathrm{~g}$ dan di masukkan ke dalam stoples perlakuan. Kemudian stoples ditutup dan digoyang dengan tujuan serbuk nabati tercampur merata dengan jagung pipil. Kemudian 10 ekor (5 pasang) imago S. zeamais dimasukkan kedalam stoples perlakua yang berisi jagung pipil dan serbuk nabati. Selanjutnya stoples ditutup dengan kain kasa dan diikat dengan karet gelang serta diberi label sesuai dengan perlakuan.

\section{Peubah yang diamati}

\section{Persentase Daya Repelensi Imago $S$. zeamais (\%)}

Daya repelensi diamati dengan cara kertas karton manila warna putih digunting melingkar dengan diameter $9 \mathrm{~cm}$ kemudian dibagi 2 bagian yang sama besar. Setelah itu bagian tengah keduanya digaris tengah dan dimasukkan dalam cawan petri yang berdiameter $9 \mathrm{~cm}$. Kemudian pada satu bagian kertas karton diberikan serbuk nabati sebanyak $10 \mathrm{~g}$ dan diratakan. Imago $S$. zeamais sebanyak 10 ekor diinvestasikan ke dalam cawan petri pada bagian yang terdapat garis dan ditutup dengan tutup petri. Setelah 2 jam, kemudian diamati jumlah serangga yang berada pada areal yang berada di serbuk nabati, dan pada areal yang tidak ada serbuk nabati. Media berbeda dengan pengamatan mortalitas, lama imago muncul, jumlah imago muncul dan kerusakan biji. Persentase daya repelensi dihitung dengan cara:

$$
\text { Daya repelensi }=\frac{\text { Jumlah imago yang menjauhi serbuk }}{\text { Jumlah imago seluruhnya }} \times 100 \%
$$

Persentase Mortalitas Imago S. zeamais (\%)

Pengamatan mortalitas imago sejak 1 Hari Setelah Aplikasi (HSA) sampai 8 HSA. Mortalitas dapat dihitung dengan rumus (Abbot, 1925 dalam Prijono, 1999).

$$
\mathrm{Po}=\frac{\mathrm{r}}{\mathrm{n}} \times 100 \%
$$

$$
\begin{aligned}
& \text { Keterangan : } \\
& \text { Po } \quad \text { = Mortalitas imago } \\
& \mathrm{r} \quad \text { = Jumlah imago yang mati } \\
& \mathrm{n} \quad \text { = Jumlah imago keseluruhan }
\end{aligned}
$$




\section{Lama Imago S. zeamais M Muncul (Hari)}

Sisa imago pada waktu setelah pengamatan mortalitas dikeluarkan dari stoples. Kemudian munculnya imago diamati pada 25 HSA sampai semua perlakuan muncul imagonya.

\section{Jumlah Imago S. zeamais Turunan Pertama yang Muncul}

Pengamatan dilakukan sejak imago turunan pertama muncul pada setiap stoples perlakuan, dan diamati selama 5 hari sampai tidak ada lagi serangga turunan pertama yang keluar pada setiap unit perlakuan.

\section{Persentase Kerusakan Biji Jagung (\%)}

Pada pengamatan ini antara biji jagung yang rusak dan biji jagung yang utuh dipisahkan,biji yang rusak ditandai dengan adanya lubang tempat keluarnya hama. kemudian ditimbang bobot biji yang utuh. Persentase kerusakan biji jagung diamati pada 64 HSA, menggunakan rumus:

keterangan :

$$
\mathrm{P}=\frac{\mathrm{b}-\mathrm{a}}{\mathrm{b}} \times 100 \%
$$

$\mathrm{P} \quad=$ Persentase kerusakan biji jagung

a $\quad=$ Bobot biji jagung yang utuh

$\mathrm{b} \quad=$ Bobot biji jagung awal seluruhnya $(100 \mathrm{~g})$

\section{HASIL DAN PEMBAHASAN}

\section{Persentase Daya Repelensi Imago S. zeamais}

Hasil pengamatan terhadap daya repelensi imago $S$. zeamais pada pengamatan 2 jam setelah aplikasi. Hasil analisis ragam menunjukkan bahwa persentase daya repelensi terhadap imago $S$. zeamais tidak berpengaruh nyata antar faktor tunggal akibat aplikasi serbuk babadotan, cengkeh, mimba dan sirsak (Gambar 1). Persentase daya repelensi imago $S$. zeamais tertinggi dijumpai pada serbuk bunga cengkeh $98,33 \%$ dan terendah pada serbuk daun sirsak yaitu $90 \%$. Hal ini dikarenakan aroma dari minyak atsiri cengkeh lebih menyengat di bandingkan dengan aroma serbuk lainnya.

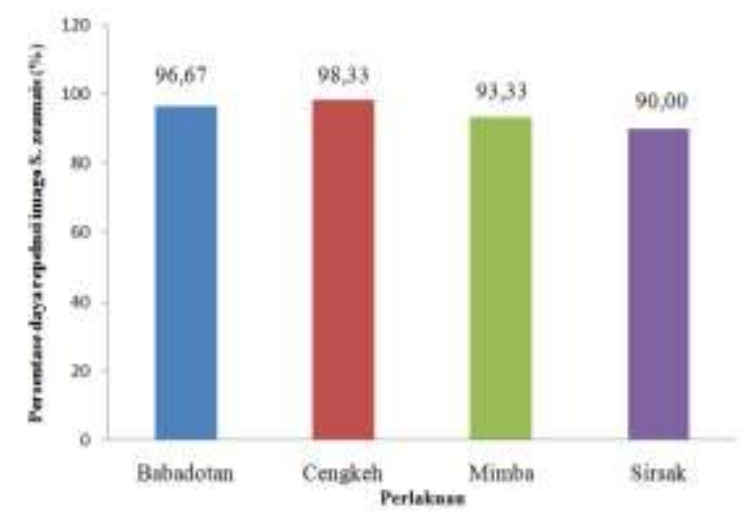

Gambar 1. Persentase daya repelensi imago $S$. zeamais 2 jam setelah aplikasi (\%)

\section{Persentase Mortalitas Imago S. zeamais}

Hasil pengamatan terhadap mortalitas imago S. zeamais pada pengamatan 1-8 HSA. Hasil analisis ragam menunjukkan bahwa persentase mortalitas terhadap hama $S$. zeamais berpengaruh nyata terhadap mortalitas $S$. zeamais. Rata-rata persentase mortalitas menunjukkan bahwa imago $S$. zeamais mengalami peningkatan kematian pada semua 
perlakuan serbuk nabati. Serbuk nabati yang paling efektif dalam mengendalikan S. zeamais adalah serbuk bunga cengkeh (Gambar 2). Angka mortalitas tertinggi 85,00\% dan terendah pada perlakuan serbuk daun sirsak dengan rata-rata mortalitas $6,67 \%$.

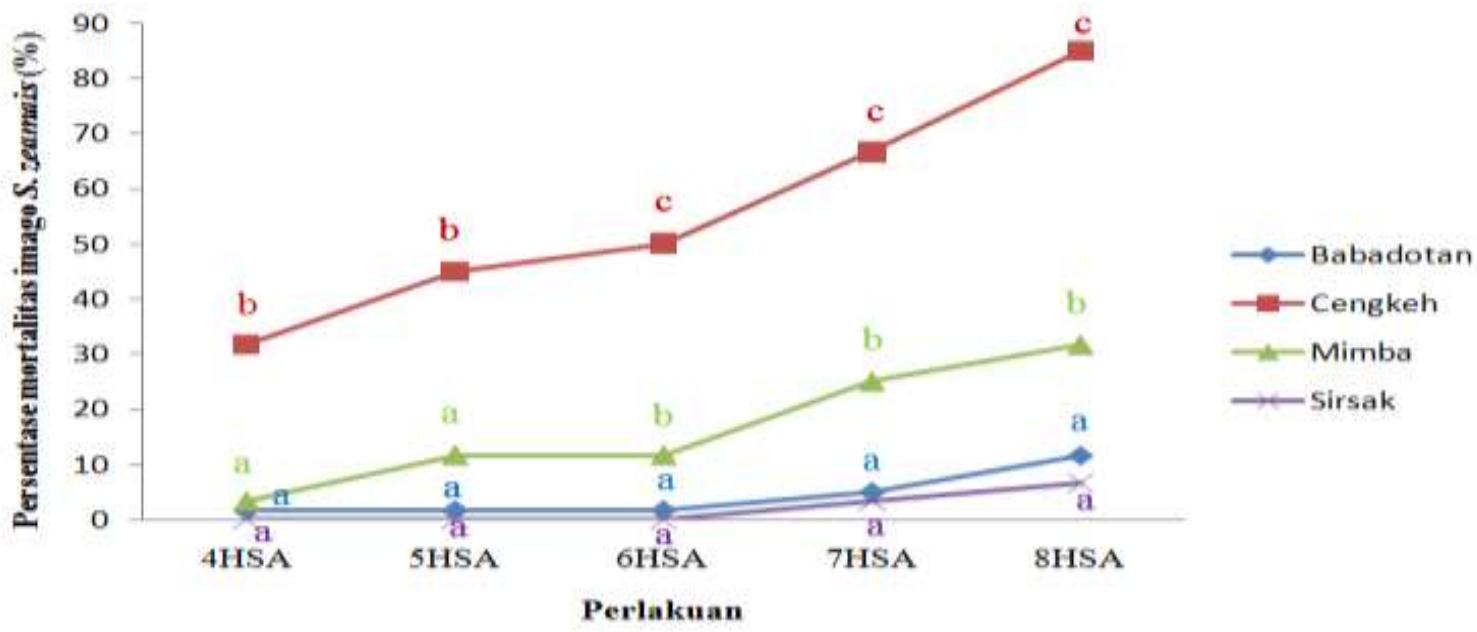

Gambar 2. Rata-rata mortalitas imago $S$. zeamais akibat beberapa aplikasi serbuk nabati pada pengamatan 4,5,6,7 dan 8 HSA

Menurut Pradana et al. (2015) serangga uji akan mengalami kelambanan gerakan, aktivitas makan berkurang dan lama-kelamaan akan mengalami kematian dengan ciri-ciri tubuh menjadi kaku, alat mulut yang menurun dan tungkai kaki menjadi kaku. Menurut Guenther (1990) salah satu kandungan terbesar cengkeh adalah Eugenol. Cara kerja senyawa dalam cengkeh mengakibatkan kemandulan dan berfungsi sebagai sterilisasi (Dorman \& Deans, 2008). Cengkeh digunakan sebagai pestisida nabati pada hama kumbang bubuk karena dapat menurunkan intensitas serangan 6,6\% dan 19,3\% mortalitas pada serangga. Hal ini dikarenakan efek kerja dari kandungan kimia cengkeh bersifat antifeedant (kekurangan nafsu makan). Mortalitas dari serangga tidak hanya disebabkan oleh efek kontak dengan pestisida nabati tetapi karena adanya starvasi, yaitu kekurangan asupan energi dan unsur-unsur nutrisi esensial yang diperlukan tubuh dalam beberapa hari sehingga menyebabkan terjadinya perubahan proses metabolisme unsur-unsur utama didalam tubuh serangga (Saenong \& Mas'ud 2009).

Beberapa penelitian selain pada media jagung juga membuktikan bahwa serbuk cengkeh efektif dalam mengendalikan hama kumbang yang sejenis dengan $S$. zeamais. salah satunya adalah Hasil penelitian Ileke \& Ogungbite (2014) menunjukkan pada 1g serbuk cengkeh dengan $20 \mathrm{~g}$ sorgum mapu mengendalikan mortalitas Sitophilus oryzae $100 \%$ dalam jangka waktu 96 jam setelah aplikasi. Cengkeh juga termasuk serbuk nabati yang efektif meskipun sudah lama disimpan. Hal ini dikarenakan faktor wadah atau alat pembungkus cengkeh tetap terjaga tanpa udara maka serbuk tetap memiliki aroma yang baik. Menurut Ofuya et al. (2010) yang menyatakan dengan menggunakan $4 \mathrm{~g}$ E. aromatica pada $20 \mathrm{~g}$ benih kacang tunggak dan 10 pasang imago Callosobruchus muculatus dimasukkan ke dalam petri plastik pada masing-masing interval umur simpan serbuk cengkeh yaitu di bawah 1 bulan, 24 bulan, 36 bulan dan 48 bulan. Keempat serbuk diaplikasikan ke srangga uji dan keempat perlakuan menghasilkan $100 \%$ kematian dalam jangka waktu 48 jam setelah aplikasi. Mortalitas terendah didapatkan pada perlakuan serbuk daun sirsak yaitu 6,67\% dan tidak efektif terhadap mortalitas hama $S$. zeamais. Hal ini diakibatkan karena bahan aktif pada serbuk daun sirsak tidak berpengaruh terhadap mortalitas imago S. zeamais. Isnaini et al. (2015) menyatakan bahwa insektisida nabati memiliki kemampuan terhadap mortalitas apabila persentase mortalitas sama atau $>50 \%$ dari yang diinvestasikan. Ketidak efektivan ini 
ada kaitannya dengan bahan aktif yang terdapat pada insektisida nabati mempunyai sifat mudah terikat dengan udara atau mudah menguap. Adapun hasil penelitian terhadap rata-rata mortalitas hama kutu beras (Sitophilus oryzae) pada pengamatan ke-7 HSA serbuk daun sirsak yaitu $2,6 \%$ dengan dosis perlakuan $15 \mathrm{~g} / 100 \mathrm{~g}$ beras.

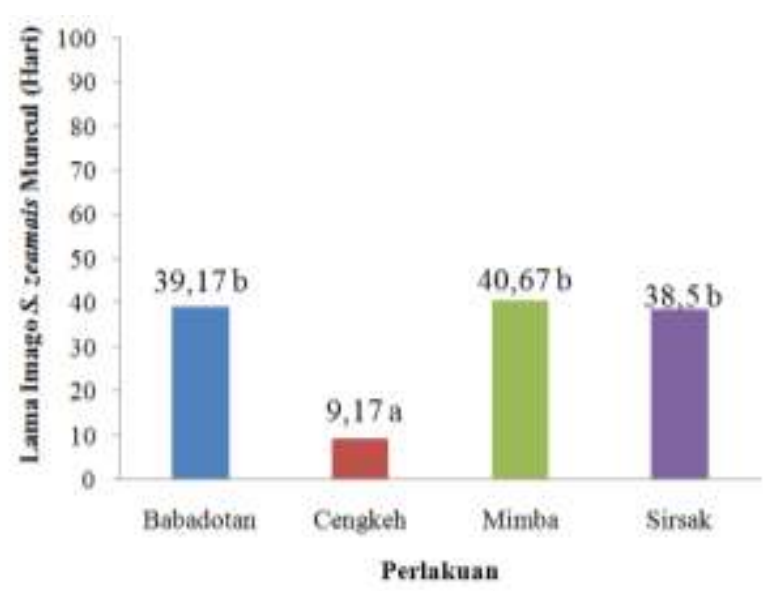

(a)

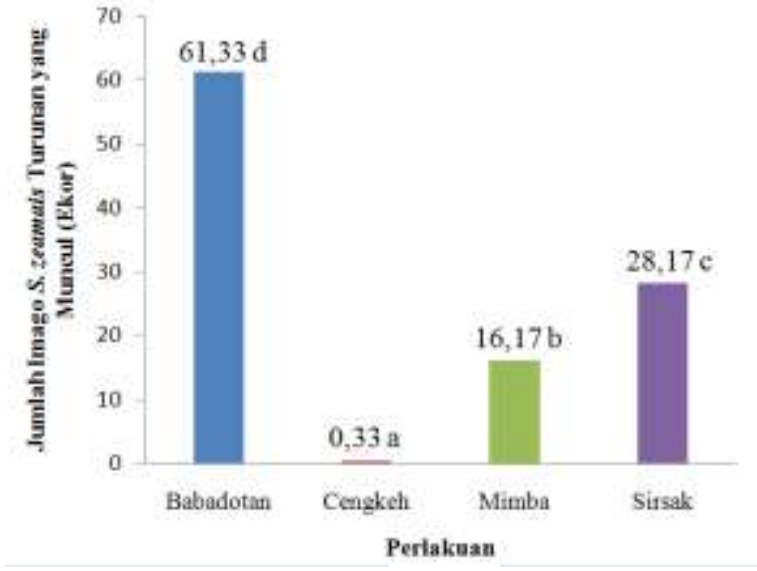

(b)

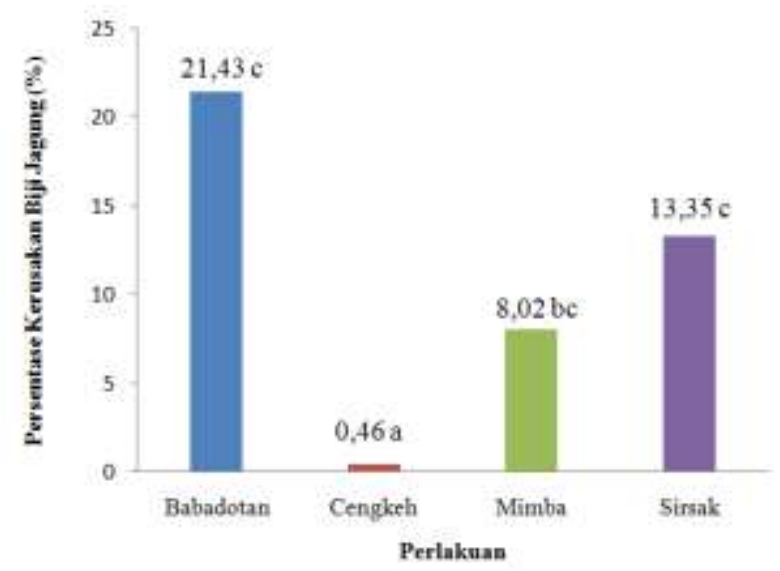

(c)

Gambar 3. (a) Lama imago S. zeamais muncul (Hari). (b) Jumlah imago S. zeamais turunan yang muncul (ekor).

(c) Persentase kerusakan biji jagung (\%)

\section{Lama Imago S. zeamais Muncul (Hari)}

Hasil pengamatan lama imago imago $S$. zeamais yang muncul pada masing-masing perlakuan. Hasil analisis ragam menunjukkan bahwa aplikasi beberapa serbuk nabati berpengaruh nyata terhadap imago $S$. zeamais. Lama imago yang muncul menunjukkan bahwa perlakuan serbuk bunga cengkeh berbeda nyata terhadap perlakuan serbuk daun babadotan, sirsak dan mimba (Gambar 3(a)). Waktu imago S. zeamais terlama muncul pada perlakuan serbuk bunga cengkeh dan tercepat pada perlakuan serbuk daun sirsak. Imago $S$. zeamais Pada perlakuan serbuk bunga cengkeh mucul pada hari ke-55 setelah aplikasi dan pada perlakuan serbuk daun sirsak imago $S$. zeamais muncul pada hari ke-37 sehingga diperoleh hasil dari rata-rata setiap ulangan 9,17 hari pada serbuk bunga cengkeh dan 38,50 hari pada serbuk daun sirsak. Lama imago $S$. zeamais muncul terjadi ada kaitannya dengan pengamatan mortalitas $S$. zeamais yang sulit berkembang. Imago cepat muncul pada 
perlakuan serbuk daun sirsak disebabkan kondisi media yang mendukung dan serbuk sudah tidak berpengaruh terhadap imago sehingga imago mampu berkembangbiak dengan baik.

\section{Jumlah Imago S. zeamais Turunan yang Muncul (Ekor)}

Hasil pengamatan jumlah imago $S$. zeamais turunan yang muncul pada masing-masing perlakuan. Hasil analisis ragam menunjukkan bahwa aplikasi serbuk berbeda nyata antara serbuk bunga cengkeh dengan, serbuk daun sirsak, serbuk daun babadotan dan serbuk daun mimba. Jumlah imago turunan yang muncul tertinggi terdapat pada perlakuan serbuk daun babadotan yaitu 61,33 imago dan yang terendah pada perlakuan serbuk bunga cengkeh yaitu 0,33 imago (gambar 3(b)). Pada serbuk bunga cengkeh terdapat 2 imago yang muncul. Imago $S$. zeamais sudah mengalami mortalitas sehingga imago tidak melakukan kopulasi dan berkembangbiak di dalam biji. Selain itu, kandungan bahan aktif yang dimiliki cengkeh sangat mempengaruhi siklus hidup imago $S$. zeamais. Hal ini ditandai dengan masih menyengatnya aroma yang dikeluarkan dari serbuk cengkeh. Cengkeh memiliki senyawa aktif yang sama yaitu flavonoid dan polifenol. Kedua senyawa ini mempunyai sifat sebagai ovisida (merusak telur) dan menghambat perkembangan larva menjadi pupa (Kinasih et al., 2013).

Imago turunan pertama yang paling banyak jumlahnya ditemui pada perlakuan babadotan. Pengaruh dari serbuk babdotan sudah tidak ada, hal ini ada kaitannya dengan aroma serbuk yang tidak terlalu menyengat sehingga aroma tidak tercium lagi. Kondisi biji jagung juga dapat mempengaruhi perkembangan siklus hama. Biji jagung yang disortir dengan kondisi biji bagus, tidak rusak dan tersedianya sumber makanan menyebabkan hama S. zeamais dapat meletakkan telur sampai menjadi imago. Hal ini dapat dilihat dari pengamatan sebelumnya karena masih ada hama yang belum mengalami mortalitas, walaupun hama tidak menyukai aromanya namun hama masih bisa meletakkan telur dan telur yang berada dalam biji mampu berkembang dengan baik sampai menjadi imago turunan pertama. Hama $S$. zeamais diketahui sudah menyerang sejak dilapangan.Telur $S$. zeamais terletak di dalam biji jagung sebelum panen maupun di gudang penyimpanan (Nonci et al., 2006). Munculnya imago pada biji jagung diduga bahwa telur $S$. zeamais sudah berada di dalam biji walaupun biji jagung terlihat baik. Hal ini dapat terjadi pada perlakuan serbuk babadotan, mimba, sirsak dan cengkeh.

\section{Persentase Kerusakan Biji Jagung (\%)}

Hasil pengamatan kerusakan biji jagung pada masing-masing perlakuan. Hasil analisis ragam berbeda nyata antara beberapa serbuk perlakuan. Kerusakan biji terendah terdapat pada perlakuan serbuk cengkeh $0,46 \%$ dan tertinggi dijumpai pada perlakuan serbuk babadotan 21,43\%. (gambar 3(c)). Hal ini juga berkaitan pada pengamatan sebelumnya. Semakin lama imago mengalami kematian maka akan memberi kesempatan untuk imago meletakkan telur dan imago turunan akan tetap hidup di dalam biji dengan kondisi aroma serbuk yang semakin lama semakin tidak berbau. Ciri-ciri biji jagung yang rusak yaitu terdapat lubang kecil yang disebabkan oleh imago $S$. zeamais sebagai tempat meletakkan telur dan berkembangbiak. Menurut Prijono (1999) insektisida nabati mudah terurai sehingga tidak berpengaruh terhadap serangga turunannya.

Menurut Hasnah et al. (2014) tujuan hama merusak tanaman yaitu sebagai tempat berlindung. Perkembangbiakkan, aktivitas dan kopulasi hama dilakukan pada siang hari dan berlangsung lebih lama dibandingkan dengan masa kopulasi hama gudang lainnya (Kartasapoetra 1987). Hama S. zeamais menyebabkan biji berlubang, cepat pecah dan hancur menjadi tepung. Hal ini ditandai dengan adanya serbuk atau tepung pada butiran yang terserang. Biji dan tepung dipersatukan oleh air liur larva yang mengakibatkan kualitas biji menjadi menurun dan biji mengalami kerusakan (Surtikanti, 2004).

\section{KESIMPULAN DAN SARAN}


Serbuk nabati bunga cengkeh memiliki keefektivan dalam mengendalikan S. zeamais di penyimpanan. Dengan menggunakan $10 \mathrm{~g}$ dosis serbuk cengkeh dan media biji jagung $100 \mathrm{~g}$ mampu mengendalikan $S$. zeamais pada pengamatan daya repelensi $98,33 \%$, mortalitas $85 \%$, lama imago muncul 9,17 hari (55 HSA), jumlah imago turunan 0,33 ekor dan kerusakan biji $0,46 \%$. Adapun saran dari penelitian ini untuk menguji serbuk nabati terhadap hama lain di penyimpanan.

\section{DAFTAR PUSTAKA}

Astriani, D. 2010. Pemanfaatan gulma babadotan dan tembelekan dalam pengendalian Sitophilus spp. Pada benih jagung. J. Agrisains. 1(1):56-67.

Brown, R.L., Z.Y, Chen., T.E, Cleveland \& J.S, Russia. 1999. Advances in the development of host resistance in corn to aflatoxin contamination by Aspergillus flavus. J. Phitopathology. 89(2):113-117.

Dorman, H.J.D dan S.G. Deans. 2008. Antimicrobial agents from plants: antibacterial activity of plant volatile oils. J. Appl Microbiology. 8:308-316.

Gani, S. 2010. Uji Efektivitas tepung daun babadotan (Ageratum conyzoides L.) terhadap kumbang beras (Sitophilus oryzae L.) (Coleoptera; curculionidae) di laboratorium. J. Manggaro. 11(1):33-35.

Gbaye, O.A., E.A. Oyeniyi., F. Adekanmbi. 2015. The efficacy of three plant powders as an entomocide against Sitophilus oryzae (Linnaeus) infesting rice grains in nigeria. J. Research Studies in Zoology. 1(1):30-35.

Gomez, K. A dan A. A. Gomez. 1995. Prosedur Statistik Untuk Penelitian Pertanian. Alih Bahasa : E. Syamsuddin \& J.S Baharsya, Universitas Indonesia. Jakarta.

Hasnah. M, Rahim. dan L, Suryanti. 2014. Efikasi serbuk lada hitam dalam mengendalikan hama S.zeamais pada biji jagung selama penyimpanan. J. Penelitian Universitas Jambi Seri Sains. 16(2):23-32.

Ileke, K.D., \& O.C. Ogungbite. 2014. Entomocidal activity of powders and extracts of four medicinal plants against Sitophilus oryzae, Oryzaephilus mercator (faur) and ryzopertha dominica (fabr.). J. Biological Sciences. 7(1):57-62.

Isnaini, M., R.P. Elfira dan W. Suci. 2015. Pengujian beberapa jenis insektisida nabati terhadap kutu beras (sitophilus oryzae L). J. Biota. 1.(1):1-8.

Kartasapoetra, A.G. 1987. Hama Hasil Tanaman dalam Gudang. Bina Aksara, Jakarta.

Kementrian Pertanian Badan Penelitian dan Pengembangan Pertanian. 2012. Pestisida Nabati. Pusat Penelitian dan Pengembangan Perkebunan. Bogor.

Kinasih, I., S. Ateng dan N. R. Roma. 2013. Uji toksisitas ekstrak daun babadotan (Ageratum conyzoides Linn) terhadap ikan mas (Cyprinus carpio Linn). Sebagai organisme nontarget. 16(2).121.132.

Martono, B., H. Ending dan L. Udarno. 2004. Plasma nutfah dan insektisida nabati. J. Perkembangan Teknologi TRO. 14:43-59.

Ofuya, T.I., O. F, Olotuah dan D.O, Akinyoade. 2010. The effect of storage on the efficacy of Eugenia aromatica (baill.) In the control of callosobruchus maculatus (fabricius) (coleoptera: bruchidae) pest. J. Appl. Sci. Environ. Manage. 14(1)97-100.

Patty, J.A. 2011. Pengujian beberapa jenis insektisida nabati terhadap kumbang Sitophilus oryzae L, pada beras. J. Agroforestri. 6(1):47-51.

Pradana, P. Y. Suratmo dan R. Rurini. 2015. Isolasi karakteristik senyawa turunan acetogenin dari daun sirsak (Annona muricata) serta uji toksisitas. J. Kimia Student. 1(1):798804. 
Prijono, D. 1999. Bahan Pelatihan Pengembangan dan Pemanfaatan Insektisida Alami. Pusat Kajian Pengendalian Hama Terpadu Institut Pertanian Bogor. Bogor.

Saenong, S.M. 2009. Kajian aspek tingkah laku serangga hama kumbang bubuk sitophilus zeamais motsch di laboratorium. Prosiding Nasional Serealia, Balai Penelitian Tanaman Serealia, Maros.

Suparjo. 2008. Saponin, peran dan pengaruhnya bagi ternak dan manusia. Laboratorium Makanan Ternak. Fakultas Peternakan. Universitas Jambi. http //:jojo66.wordpress.com. [20 Mei 2018].

Trisnadi, R. K. Sp.2016. Pestisida Nabati Ramah Lingkungan Untuk Mmengendalikan Hama Dan Penyakit Tanaman; Probolinggo: Dinas Perkebunan Dan Kehutanan.

Yanti, F. 2016. Pengaruh campuran serbuk daun babadotan dan serbuk daun sirsak terhadap mortalitas serta perkembangbiakan Sitophilus zeamais pada jagung di penyimpanan. Skripsi. Program Studi Agroteknologi, Fakultas Pertanian Universitas Syiah Kuala, Banda Aceh. 